\title{
DO OTIMISMO LIBERAL À GLOBALIZAÇÃO ASSIMÉTRICA: A POLÍTICA EXTERNA DO GOVERNO FERNANDO HENRIQUE CARDOSO $(1995-2002)^{1}$
}

\section{Carolina Rigotti Coutinho ${ }^{2}$}

André Luiz Reis da Silva é mestre em História e doutor em Ciência Política pela Universidade Federal do Rio Grande do Sul (UFRGS), sendo professor adjunto do Curso de Relações Internacionais, do Programa de Pós-Graduação em Ciência Política e Estudos Estratégicos Internacionais, todos na UFRGS.

No livro "Do Otimismo Liberal à Globalização Assimétrica", fruto de sua tese de doutorado defendida em 2008, o autor faz uma análise da política externa de Fernando Henrique Cardoso em seus dois mandatos. Com isso, desde o início deixa claro que sua intenção é estudar, além da política externa em si, o "pacto interno que permitiu a formulação e implantação da política externa de Fernando Henrique Cardoso" (p.22), trabalhando com a ideia de que "a política externa é a dimensão externa da política” (p.33).

Dentro dessa discussão a respeito da formulação teórica para a análise, o autor situa a política externa como resultado de pressões tanto internas como externas, sendo que o Estado não pode ser visto como um agente "neutro" que define a estratégia nacional, e sim como esta sendo o resultado dessas pressões e lutas de interesses

\footnotetext{
${ }^{1}$ SILVA, André Luiz Reis da. Do Otimismo Liberal à Globalização Assimétrica: a política externa do governo Fernando Henrique Cardoso (1995-2002). Curitiba: Juruá, 2009. ISBN: 978-85-362-2753-5.

${ }^{2}$ Mestranda em Ciência Política pela UFRGS. carolinarcoutinho@gmail.com
} 


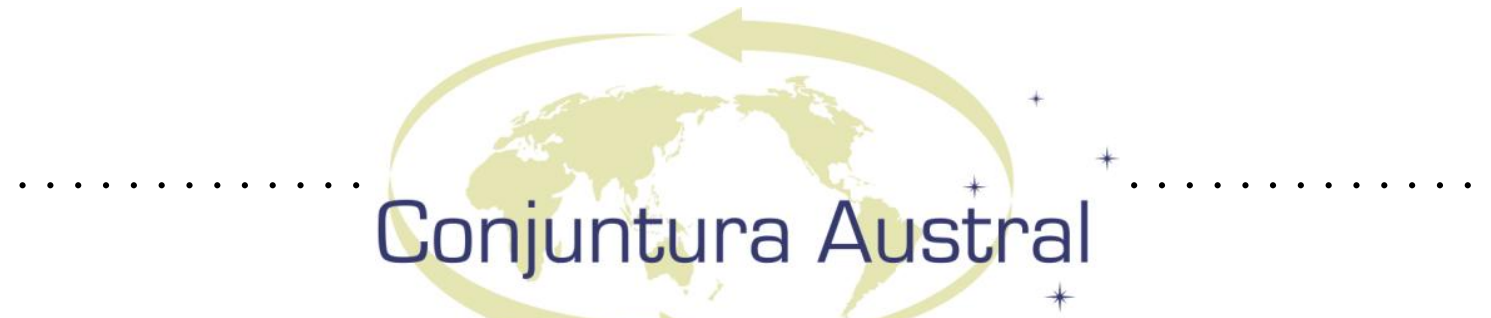

diversos. Cabe ressaltar que esta discussão se encontra de maneira resumida no livro, sendo possível acompanhar com maior profundidade na tese do autor.

Ademais, procura identificar mudanças e continuidades em relação à política externa anterior, testando o conceito de matriz em sua análise, utilizado por Ricardo Sennes, identificando uma mudança de matriz nos anos 1990, já com o governo Collor. Para tanto, também traça um panorama da conjuntura internacional nesse período, verificando a atuação brasileira nas diversas frentes.

Para levar a cabo estes objetivos, são utilizados como fontes documentos produzidos pelo Itamaraty, Mensagens Presidenciais ao Congresso Nacional, discursos do Presidente da República, entre outros. É interessante frisar o trabalho minucioso do autor ao utilizar notícias de jornais e revistas para embasar a pesquisa e tornar sólidos os argumentos. De maneira geral, são apresentados fatos bastante detalhados que exemplificam o contexto e tornam mais claro o entendimento do argumento.

Com isso, a análise se divide em cinco capítulos, além da introdução. No primeiro, "os condicionamentos na formulação da política externa do governo Fernando Henrique Cardoso", é feita a análise do contexto internacional e as mudanças ocorridas no pós-Guerra Fria, ajudando a situar o leitor. Discute-se também a diplomacia presidencial, de grande destaque nesse período, chegando à conclusão de que não houve diminuição do papel do Itamaraty, mas sim um "maior compartilhamento de funções, com a diplomacia profissional atuando em conjunto com outros órgãos do Governo" (p.91). A respeito dos demais atores, frise-se que, apesar dessa centralização da diplomacia presidencial, o debate a respeito da política externa ampliou-se, envolvendo empresários, sindicatos, ONGs entre outros. Um dos exemplos mais notórios desse fato foi o debate a respeito da Área de Livre Comércio das Américas (ALCA).

A seguir, no segundo capítulo, o autor faz uma discussão a respeito do conceito de "neoliberalismo", discutindo as diferentes interpretações e a aplicação desta definição para o governo de Fernando Henrique. Como conclusão, coloca que neste período o Brasil não aplicou na íntegra o projeto neoliberal, sendo por isso mais interessante conceituá-lo como "neoliberalismo matizado". Porém isso se mantém apenas até 1999, momento em que há uma inflexão na política externa brasileira, 


\section{Conjuntura Austral}

havendo crescentes críticas por parte do Brasil em relação à estrutura do sistema internacional.

Por fim, nos três últimos capítulos, é feita a análise das relações brasileiras em termos hemisféricos, extra hemisféricos e participação brasileira nos fóruns multilaterais, respectivamente. Em relação às relações hemisféricas, pode-se notar a maior atenção dada às relações regionais, sendo um espaço realista da inserção internacional brasileira. Quanto às relações com os Estados Unidos, se observa por parte do Brasil uma busca de liberdade de atuação, além de, em relação à ALCA, procurar "ganhar tempo e realizar barganhas articuladas em outras esferas, como a União Europeia e a OMC" (p.314-315). Dentro desta visão também se percebe as relações com os demais países, podendo ser notada uma maior multilateralização dentro dessa estratégia de autonomia. Porém é importante ressaltar a seletividade das relações, demonstrada pelo conceito de parceria estratégia.

Já quanto ao espaço multilateral, um conceito utilizado para explicar a atuação brasileira no período é a de "autonomia pela participação". "Assim, a trajetória rumo ao desenvolvimento se daria não pelo confronto no sistema internacional, mas pela participação na construção do seu funcionamento, de forma a potencializar a inserção internacional do pais" (p.317).

Com isso, é mostrado que durante o governo Fernando Henrique, a matriz neoliberal entrou em crise, sendo que o "otimismo liberal (toda liberalização é ótima e necessária) passou a ser substituído, pelo Governo, por uma crítica à 'globalização assimétrica' (que estava gerando mais descompasso entre os países)"(p.319).

Por conseguinte, pode-se dizer que é um livro recomendado para todos aqueles interessados no período de uma maneira geral, pois trata não apenas da política externa, com a questão da mudança da matriz desenvolvimentista para a neoliberal e sua crise ao final do governo, mas também dos fatores internos que a influenciam.

Artigo recebido dia 27 de março de 2011. Aprovado dia 15 de abril de 2011. 